\title{
EVALUATION OF THE FUNGITOXIC ACTIVITY OF VEGETAL EXTRACTS ON THE MYCELIAL GROWTH OF PHYTOPATHOGENS
}

\author{
AVALIAÇÃO DA ATIVIDADE FUNGITÓXICA DE EXTRATOS VEGETAIS SOBRE O \\ CRESCIMENTO MICELIAL DE FITOPATÓGENOS
}

\author{
Talita Pereira de Souza FERREIRA ${ }^{\mathbf{1}}$; Gil Rodrigues dos SANTOS $^{\mathbf{1}}$; \\ Tatiani Pereira de Souza FERREIRA ${ }^{1}$; Tallyta Santos TEIXEIRA ${ }^{1}$; Ryhára Dias BATISTA $^{1}$; \\ Raiana Batista da LUZ ${ }^{1}$; Luiz Gustavo de Lima GUIMARÃES ${ }^{2}$ \\ 1. Universidade Federal do Tocantins, Gurupi, TO, Brasil. cupufer@ gmail.com; 2. Universidade Federal de São João Del Rei, \\ São João Del Rei, MG, Brasil.
}

\begin{abstract}
Although the productivity of common bean in Tocantins is economically favorable, it has been infected by various pathogens found in soil. Among the major diseases is the web blight and root rot caused by Rhizoctonia solani and collar rot caused by the fungus Sclerotium rolfsii. This study aimed to evaluate the fungitoxic activity of methanol extracts of eight plant species on the inhibition of mycelial growth of $S$. rolfsii and $R$. solani. The fungitoxic activities were carried out over the inhibition of mycelial growth by means in vitro assays. The extracts were applied in concentrations of 250, 500, 1000, 2500 e $5000 \mathrm{~g} \mathrm{ml}^{-1}$ in PDA culture medium. In bioassays, it was found the significant effect of plant, concentration and also their interaction on the antifungal activity of the extracts. However, some extracts showed no inhibition of mycelial growth of the pathogens studied. Among those who had higher inhibitions is the extract of Lantana trifolia, which inhibited the mycelial growth of S. rolfsii in all concentrations, being the same as $97 \%$ for the highest concentration. When the methanol extract of Piper amplum Kunth, inhibition of the highest concentration was $83 \%$ for S. rolfsii and $74 \%$ for $R$. solani. These results show the potential of methanolic extract of Lantana trifolia and Piper amplum Kunth in the control set of plant pathogens studied.
\end{abstract}

KEYWORDS: Methanol extract. Sclerotium rolfsii. Rhizoctonia solani. Phaseolus vulgaris.

\section{INTRODUCTION}

The common bean (Phaseolus vulgaris) is the most important legume crop consumed by humans worldwide. Various pathogens of epidemiological importance can damage common bean crops reducing their quality (PARSA et al., 2016). The risk of losses caused by pests and diseases in bean decreases the profitability for producers, resulting in decreased exploitation of this legume by large producers (GONÇALVESVIDIGAL et al., 2007; CUNHA et al., 2005). Therefore, there is a growing interest in discovering plant-derived anti-microbial substances as alternative agents against fungal growth (ELMOUGY et al., 2007).

Of the 60 diseases that can affect bean crops, 31 are caused by fungi. These pathogens are reported as the primary causative agents of diseases in the economically important vegetable crops. Each year they destroy a third of agricultural production worldwide resulting in approximately $20 \%$ reduction in yield of cultivars (GARCIA et al., 2002). Among the diseases caused by pathogenic fungi in bean crops, there are the collar rot and the web blight which are caused by the fungi Sclerotium rolfsii and Rhizoctonia solani, respectively.
So, to avoid significant losses caused by diseased plants, several control methods are currently employed. The most common being the use of synthetic fungicides (BAJWA; KHALID; CHEEMA, 2003). However, the abusive use of these compounds has been causing environmental damage and has even been proven harmful for consumers, besides promoting resistance of the pathogenic microorganisms. Furthermore, these synthetic fungicides also affect the symbiotic microbial population present in the local ecosystem (CUNICO et al., 2004). In view of this, ongoing research is being conducted in order to create and/or discover new methods to halt the advance of pathogenic fungi growth which are environmentally friendly and effective in the action.

Extracts from different parts of medicinal plants have been the source of many compounds that have antimicrobial activities. Many studies have reported the fungitoxic activity of various plant extracts. For instance, Vogt et al. (2012), while studying the effects of the extract of a medicinal plant from Argentina, Larrea divaricata, corroborated its empirical use in the treatment of some plant diseases and showed high rate of antifungal activity, making it a potential natural source for biological control. Fiori et al. (2000) reported that the extracts from the leaves of 
Eucalyptus citriodora inhibited the mycelial growth of the pathogenic fungus Didymella bryoniae, while the plant extract of Achillea millefolium inhibited the germination of spores of the same fungus. Also in this work, the plant extract Ageratum conyzoides both inhibited the growth of mycelial and spore germination of the fungus Didymella bryonae.

Given the above, this work aimed to study the fungitoxic activity of methanol extracts of eight plant species on the inhibition of mycelial growth Sclerotium rolfsii and Rhizoctonia solani, in order to develop alternative and effective means to control the collar rot, web blight and root rot caused by these pathogens in the culture of the common bean.

\section{MATERIAL AND METHODS}

\section{Collection and extraction of vegetal plant extracts}

Eight plant species were studied: 'sucupira' (Pterodon emarginatus), 'mastruz' (Chenopodium ambrosioides), mint (Mentha piperita), terramycin (Alternanthera dentata), 'negramina' (Siparuna guianensis Aublet), pepper (Piper amplum Kunth), 'camará' (Lantana trifolia L.) and 'grandiúvad'anta' (Psychotria leiocarpa Cham. Et Schlechtend). After harvesting, the plant material was sent to the Chemistry Laboratory on the UFT Campus in Gurupi, where they underwent drying and processes to obtain the extracts. The leaves were dried in the shade at room temperature and subsequently were cut and submitted to extraction with cold methanol. Thirty grams of dried leaves were used with 1.5 liters of solvent for each extraction for a period of 7 days. After this period, the mixture was filtered and evaporated under reduced pressure to obtain the extracts (COSTA et al., 2008).

\section{Isolation of fungi used in biological assay}

The pathogens $S$. rolfsii and $R$. solani were isolated from plants of the common bean Phaseolus vulgaris with symptoms of the disease (collar rot and root rot) as follows: plant parts with symptoms of the disease were cut and washed in water. Then these pieces were surface sterilized by successive immersion in $70 \%$ ethanol for 30 seconds, a solution of $1 \%$ sodium hypochlorite for 40 seconds and three times in demineralized water. After being washed several times, they were transferred with sterile tweezers to a Petri plate containing $15 \mathrm{ml}$ of PDA culture medium (Potato Dextrose Agar) and $1 \mathrm{mg}$ of ampicillin. Daily, the Petri dishes were monitored and fungal colonies that showed no contaminants were transplanted into new plates with the same culture medium (VALADARES et al. 2008).

\section{Experimental design and biological activity}

Isolated pure cultures of plant pathogens $S$. rolfsii and $R$. solani that were 7 days old were separately tested to evaluate fungitoxicity. Bioassays were conducted by adding to the PDA culture medium $\left(\right.$ Sigma-Aldrich $\left.^{\circledR}\right)$, aqueous solutions of methanol extracts from the eight lyophilized medicinal plants, examined in appropriate volumes to obtain concentrations of $250,500,1000,2500$ and $5000 \mu \mathrm{g} \mathrm{mL}^{-1}$, equally for each microorganism. With the medium already poured into Petri dishes, discs of agar-mycelium of $5 \mathrm{~mm}$ diameter made of pure cultures of fungi were inoculated on the surface of each culture with their respective treatments. Subsequently, the plates were sealed with plastic film and incubated in a growth chamber $\left(25 \pm 1{ }^{\circ} \mathrm{C}\right)$ and exposed to a photoperiod of 12 hours. To estimate the efficiency of the treatments, the diameter of each of the colonies was measured during the mycelial growth and compared to that of absolute witness. It was observed that it completely covered the surface of the medium. The radial growth was measured with calipers in two orthogonal axes to each other by calculating an average for each plate. The experimental design was completely randomized with three replications. Treatments were arranged in a factorial scheme $2 \mathrm{x}$ $8 \times 5$ for evaluation as antifungal activity being constituted by combinations of the eight plant species, two pathogenic fungi and concentrations of extracts. Analysis of variance was carried out to check the effects of treatments, using regression analysis to assess the percentage of inhibition of mycelial growth of phytopathogenic fungi, in relation to concentration using the statistical program SISVAR.

\section{RESULTS AND DISCUSSION}

According to the results of the assessment of the fungitoxic activity of plant extracts from eight plant species studied, there was a significant effect on plant factors, concentration, and also the interaction of these factors on antifungal activities presented by the extracts and applied to each test performed. Through this interaction, we observed the existence of a variation of antifungal activity, depending on the extract of each plant and the concentration of each. The values of antifungal activity in the plant extracts in relation to their concentrations are assessed by inhibition assay in 
percentages for the two fungi $S$. rolfsii and $R$. solani

are shown in Figure 1.

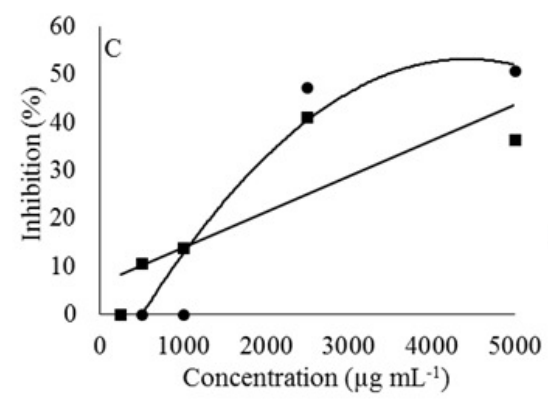

- . solani $\mathrm{y}=-3,8771^{*} \mathrm{x}^{2}-8,4069^{*} \mathrm{x}+2,142 \mathrm{R}^{2}=0,8398$

- $S$ rolfsii $\mathrm{y}=10,275^{*} \mathrm{x}-10,549 \quad \mathrm{R}^{2}=0,8598$

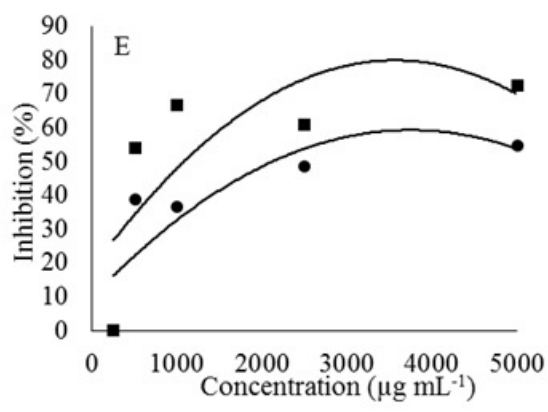

-R. solani $\mathrm{y}=-3,64 * \mathrm{x}^{2}+33,744 * \mathrm{x}-25,478 \mathrm{R}^{2}=0,8864$

- $S$ rolfsii $\mathrm{y}=-6,9214^{*} \mathrm{x}^{2}+57,267^{*} \mathrm{x}-44,998 \mathrm{R}^{2}=0,9263$

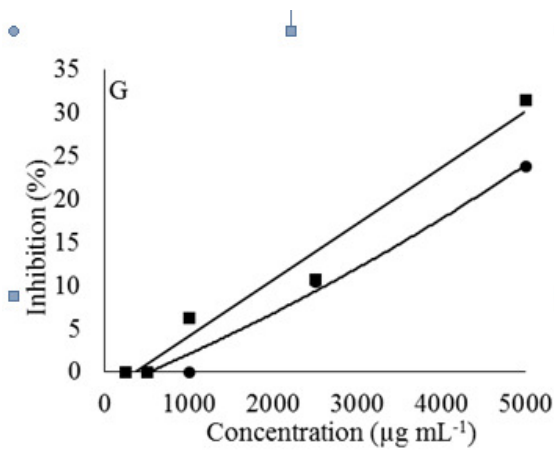

-R. solani $\mathrm{y}=2,6536 * \mathrm{x}^{2}-10,112 * \mathrm{x}+8,004 \mathrm{R}^{2}=0,9876$

- $S$ rolfsii $\mathrm{y}=3,141 * \mathrm{x}-3,997 \mathrm{R}^{2}=0,894$

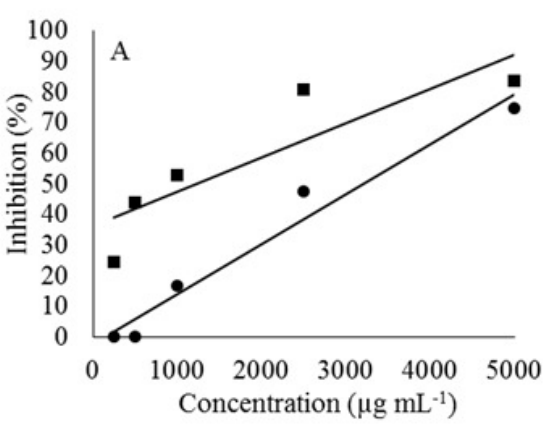

- R. solani $\mathrm{y}=19,714^{*} \mathrm{x}-31,286 \quad \mathrm{R}^{2}=0,9118$

- $S$ rolfsii $\mathrm{y}=15,524^{*} \mathrm{x}+10,52 \quad \mathrm{R}^{2}=0,955$

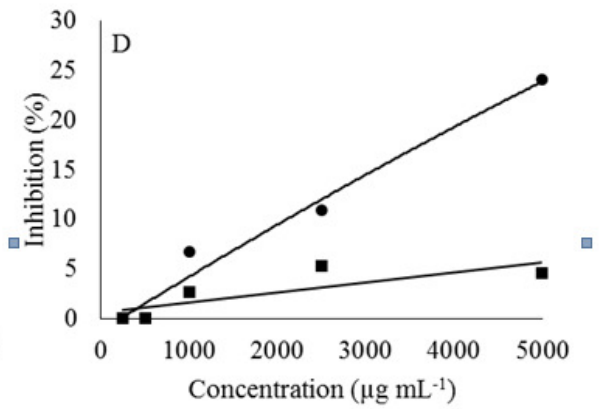

- R. solani $\mathrm{y}=1,6879 * \mathrm{x}^{2}-4,2221 * \mathrm{x}+2,452 \mathrm{R}^{2}=0,9832$

- $S$. rolfsii $\mathrm{y}=1,428^{*} \mathrm{x}-1,808 \mathrm{R}^{2}=0,8462$

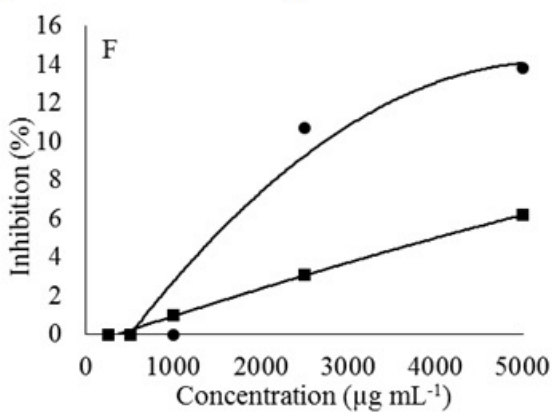

-R. solani $\mathrm{y}=-1,2079^{*} \mathrm{x}^{2}-3,4141^{*} \mathrm{x}+1,86 \mathrm{R}^{2}=0,9037$

- $S$ rolfsii $\mathrm{y}=-52,79 * \mathrm{x}^{2}+1,6201 * \mathrm{x}+1,1 \mathrm{R}^{2}=0,9999$

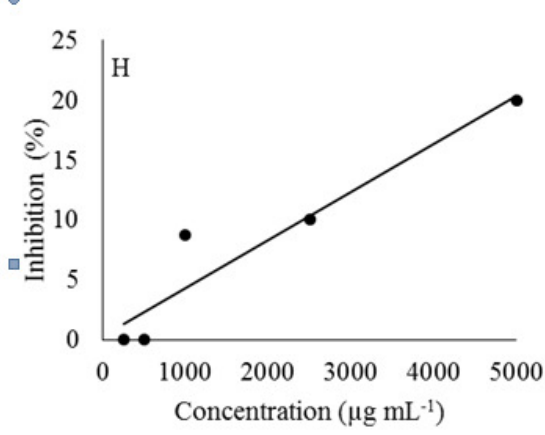

$\bullet_{R}$ solani $\mathrm{y}=5,8103 * \mathrm{x}-8,049 \mathrm{R}^{2}=0,9246$

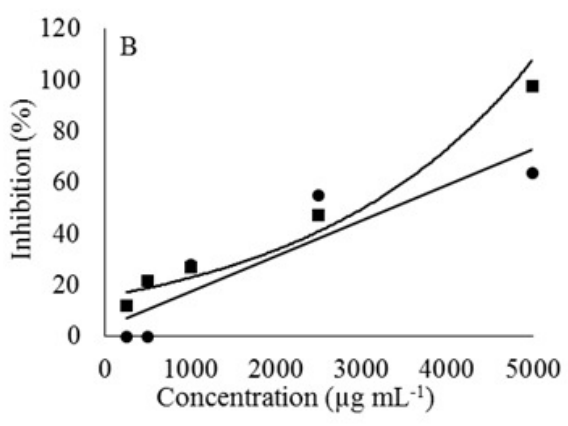

-R. solani $\mathrm{y}=18,238 * \mathrm{x}+25,382 \mathrm{R}^{2}=0,935$

- $S$ rolfsii $\mathrm{y}=6,9386 * \mathrm{x}^{2}-22,023 * \mathrm{x}+30,758 \quad \mathrm{R}^{2}=0,9736$

Figure 1. Fungitoxic activity of the methanol extracts of the ten plant species on mycelial growth of pathogenic fungi Sclerotium rolfsii and Rhizoctonia solani. A: Piper amplum; B: Lantana trifolia; C: Mentha piperita; D: Chenopodium ambrosioides; E: Psychotria leiocarpa; G: Siparuna guianensis; H: Pterodon emarginatus; I: Alternanthera dentata. 
The effect of the extract L. trifolia (Figure 1B) against $R$. solani was observed when the witness completely covered the Petri dish. The mycelial growth was reduced at concentrations of 1000,2500 and $5000 \mu \mathrm{g} \mathrm{ml}^{-1}$, and there was inhibition at the highest concentration of $64 \%$. Already with the fungus, $S$. rolfsii, the methanol extract showed this inhibitory effect at all concentrations used. An inhibition of $97 \%$ was observed in the highest concentration.

Likewise, the extract of Psychotria leiocarpa (Figure 1E) significantly reduced the growth of mycelia of both fungi studied. The inhibition was verified from concentration of 5000 $\mu \mathrm{g} \mathrm{ml}^{-1}$, while the highest concentration obtained $72 \%$ mycelial inhibition in $S$. rolfsii and $55 \%$ in $R$. solani. When these same fungi were exposed to the extract Piper amplum (Figure 1A), inhibition of the highest concentration was $83 \%$ for $S$. rolfsii and $75 \%$ for $R$. solani, considering the inhibitions were observed from lower concentrations.

According to the regression analyses for the two pathogenic fungi, mycelial inhibition in relation to concentrations of methanol extracts of $L$. trifolia (Figure 1B) and of P. leiocarpa (Figure 1E), which follow equations of the second order. Already having considered the concentrations of the extract of $P$. amplum (Figure 1A), which follow equations of the first order.

The assessment of the potential fungitoxic plant extract $A$. dentata (Figure $1 \mathrm{H}$ ), showed no effect on the inhibition of mycelial pathogen $S$. rolfsii. On the other hand, the pathogen $R$. solani was sensitive to all extracts of plants assessed. But some extracts even at the highest concentration showed lower percentage inhibition of mycelial growth even though the extracts; $P$. emarginatus (Figure 1G), C. ambrosioides (Figure 1D), $S$. guianensis (Figure 1F) and A. dentata (Fig. 1H), exhibited the following activities: 24, 24, 14 and $20 \%$, respectively. Considering the fact that concentration varies according to the regression analyses, the mycelial inhibition of these extracts followed equations of the second degree, except for the inhibitions caused by the different concentrations of the extract $A$. dentata (Figure $1 \mathrm{H}$ ), which followed an equation of first degree. The extracts of M. piperita (Figure 1C), C. ambrosioides (Figure 1D), S. guianensis (Figure 1F) and $P$. emarginatus (Figure 1G) also had no significant effects on the inhibition of mycelial growth of phytopathogenic fungus $S$. rolfsii, since before their concentration was increased, the mycelial growth of this microorganism was inhibited by 36, 4, 6 and $10 \%$, respectively. However, the methanol extract of
$M$. piperita (Figure 1C) on $R$. solani showed a significant inhibition of $51 \%$ at its highest concentration.

Many studies have presented results which corroborate those found in this work, as conducted with plant extracts of Ocimum basilicum (basil), Ruta graveolens (rue), Baccharis trimera (gorse), which showed antifungal activity on Rhizoctonia solani, Sclerotium rolfsii, Alternaria alternata, Phythophtora sp. and Colletotrichum graminicola (STARGALIN et al., 1999). Significant effects were observed in a concentration of $1 \%$ applied to the turmeric extract which has led to a greater than $50 \%$ inhibition of growth of Fusarium oxysporum (61\%) and $R$. solani (61\%) (AMARAL; BARA, 2005). Thangavelu et al. (2004) showed that extracts of Solanum torvum, Jatropha glandulifera and Emblica officinalis were highly inhibitory to mycelial growth of Colletotrichum musae, such inhibitions being directly related to the concentration factor. Extracts of leaves and seeds of Pithecellobium dulce had fungitoxic effects in more than 50\% mycelial growth and sporulation of Botrytis cinerea, Penicillium digitatum and Rhizopus stolonifer, the strawberry fruit (BAUTISTA-BAÑOS et al., 2003).

\section{CONCLUSIONS}

Among the methanol extracts of the plants studied, the one showing the best antifungal effect on mycelial growth of the fungus $S$. Rolfsii was the methanol extract of the plant L. trifolia with inhibition of $97 \%$.

For $R$. Solani, the methanol extract of $P$. amplum showed the best result among all extracts evaluated, inhibiting 75\% growth of mycelia. Furthermore, observing the percentages of inhibition of the two fungi in general, $S$. rolfsii was more resistant to plant methanol extracts than all pathogens studied.

These results show that the potential of methanol extracts for L. trifolia and P. amplum in the control group of plant pathogens studied. However, it is necessary to conduct further studies employing fractionation on the extract, for identification of molecule(s) performing such activities.

\section{ACKNOWLEDGEMENTS}

This work was supported by the Conselho Nacional de Desenvolvimento Científico e Tecnológico - CNPq - Brazil. 
RESUMO: Apesar da produtividade do feijão comum no Tocantins ser economicamente favorável, o mesmo pode ser infectado por vários patógenos habitantes do solo, dentre as principais doenças encontra-se a mela e a podridão radicular causadas pelo fungo Rhizoctonia solani e a podridão do colo causada pelo fungo Sclerotium rolfsii. Este trabalho teve como objetivo avaliar a atividade fungitóxica dos extratos metanólicos de oito espécies vegetais sobre a inibição do crescimento micelial de Sclerotium rolfsii e Rhizoctonia solani. As atividades fungitóxicas foram realizadas perante a inibição do crescimento micelial por meio de ensaios in vitro, sendo os extratos aplicados nas concentrações de 250,500 , 1000,2500 e $5000 \mu \mathrm{g} \mathrm{ml}^{-1}$ em meio de cultura BDA. Observou-se o efeito significativo dos fatores planta, concentração e também da interação destes sobre as atividades fungitóxicas. No entanto, alguns extratos não apresentaram inibição do crescimento micelial dos fitopatógenos estudados. Entre os que apresentaram maiores inibições encontra-se o extrato de Lantana trifolia, que inibiu o crescimento micelial do $S$. rolfsii em todas as concentrações, sendo o mesmo de $97 \%$ para a maior concentração. Já a concentração mais elevada do extrato metanólico de Piper amplum apresentou inibição de 83\% sobre o crescimento micelial de $S$. rolfsii e $74 \%$ sobre o crescimento micelial de $R$. solani. Tais resultados evidenciam a potencialidade dos extratos metanólicos das folhas de Lantana trifolia e de Piper amplum no controle dos fitopatógenos estudados.

PALAVRAS-CHAVE: Extrato metanólico: Sclerotium rolfsii. Rhizoctonia solani. Atividade fungitóxica.

\section{REFERENCES}

AMARAL, M. F. Z. J.; BARA, M. T. F. Avaliação da atividade antifúngica de extratos de plantas sobre o crescimento e fitopatógenos. Rev. Eletr. de Farm., Goiânia, v. 2, (Supl.), n. 2, p. 5- 8, 2005.

BAJWA, R.; KHALID, A.; CHEEMA, T. Antifungal activity of allelopathic plant extracts III: growth response of some pathogenic fungi to aqueous extract of Parthenium hysterophorus. Pak. J. Plant Pathol. New York, v. 2, n. 3, p. 145-156, 2003.

BAUTISTA-BAÑOS, S.; GARCÍA-DOMÍNGUEZ, E.; BARRERA-NECHA, L. L.; REYES-CHILPA, R.; WILSON, C. L. Seasonal evaluation of the postharvest fungicidal activity of powders and extracts of huamuchil (Pithecellobium dulce): action against Botrytris cinerea, Penicillium digitatum and Rhizopus stolonifer of strawberry fruit. Postharvest Biol. Tec., Washington, v. 29, p. 81-92, 2003.

COSTA, F. J.; BANDEIRA, P. N.; ALBURQUERQUE, M. R. J. R.; PESSOA, O. D. L.; SILVEIRA, E. R.; BRAZ-FILHO, R. Constituintes químicos de Vernonia chalybaea Mart. Quim. Nova, São Paulo, v. 31, n. 7, p. 1691-1695, 2008.

CUNHA, J. P. A. R.; TEIXEIRA, M. M.; VIEIRA, R. F. Avaliação de pontas de pulverização hidráulicas na aplicação de fungicida em feijoeiro. Cienc. Rural, Santa Maria, v. 35, n. 5, p. 1069-1074, 2005. https://doi.org/10.1590/S0103-84782005000500013

CUNICO, M. M.; CARVALHO, J. L. S.; SILVA, V. C.; MONTRUCCHIO, D. P.; KERBER, V. A.; GRIGOLETTI JÚNIOR, A.; AUER, C. G.; MIGUEL, M. D.; MIGUEL, O. G. Avaliação antifúngica de extratos obtidos de Ottoniamartiana Miq. (Piperaceae) sobre três fitopatógenos. Arq. Inst. Biol., São Paulo, v. 71, (Supl.), p. 1-749, 2004.

EL-MOUGY, N. S.; EL-GAMAL, N. G.; ABDEL-KADER, M. M. Control of wilt and root rot incidence in phaseolus vulgaris L. by some plant volatile compounds. J. Plant Prot. Res., v. 47, n. 3, p. 255-265, 2007.

FIORI, A. C. G.; SCHWAN-ESTRADA, K. R. F.; STANGARLIN, J. R.; VIDA, J. B.; CRUZ, M. E. S.; PASCHOLATI, S. F. Antifungal activity of leaf extracts and essential oils of some medicinal plants against Didymella bryoniae. J. Phytopathol., Malden, v. 148, p. 483-487, 2000.

GARCIA, L. C.; JUSTINO, A.; RAMOS, H. H. Análise da pulverização de um fungicida na cultura do feijão em função do tipo de ponta e do volume aplicado. Bragantia, Campinas, v. 61, n. 3, p. 291-295, 2002.

https://doi.org/10.1590/S0006-87052002000300011 
GONÇALVES-VIDIGAL, M. C; BONETT, L. P; FILHO, P. S. V; GONELA, A; RIBEIRO, A. S. Genetic controlo in the performance of common bean diferential cultivars to Colletotrichum lindemuthianum races. Arq. Biol. Tecnol., Curitiba, v. 50, n. 4, p. 579-586, 2007.

PARSA, S. GARCÍA-LEMOS, A. M.; CASTILLO, K.; ORTIZ, V.; LOPEZ-LAVALLE, L. A. B.; BRAUN, J.; VEGA, F. E. Fungal endophytes in germinated seeds of the common bean, Phaseolus vulgaris. Fun. Bio., v. 120, p. 783-790, 2016.

STANGARLIN, J. R; SCHWAN-ESTRADA, K. R. F; SILVA CRUZ, M. E; NOZAKI, M. H. Plantas Medicinais e Controle Alternativo de Fitopatógenos. Biotecnol. Ciênc. Desenv., Brasília, n.11, p.16-21, 1999.

THANGAVELU, R; SUNDARARAJU, P; SATHIAMOORTHY, S. Management of Anthracnose Disease of Banana Caused by Colletotrichum Musae Using Plant Extracts. J. Hort. Sci. Biotechnol., Dundee, v. 79, p. 664-668, 2004.

VALADARES, R. B. S; PEREIRA, M. C; KASUYA, M. C. M; CARDOSO, E. J. B. N. Isolamento e Identificação de Fungos Micorrízicos de Gomeza sp. (Orchidaceae) em uma Floresta de Araucária do Estado de São Paulo. In: Fertbio, 2008, Londrina. Anais..., p. 255-258, 2008.

VOGT, V; CIFUENTE, D; TONN, C; SABINI, L; ROSAS, S. Antifungal Activity In Vitro and In vivo of Extracts and Lignans Isolated from Larrea Divaricata Cav. Against Phytopathogenic Fungus. Ind. Crops Prod., St Martin d'Heres, v. 42, p. 583- 586, 2012. 